http://jmscr.igmpublication.org/home/

ISSN (e)-2347-176x ISSN (p) 2455-0450

crossref DOI: https://dx.doi.org/10.18535/jmscr/v10i1.21

Journal Of Medical Science And Clinical Research

IGM Publication

An official Publication of IGM Publication

\title{
To Study the Effects of Comparison of Insulin plus OHA versus Combination of OHA Alone in Type 2 Diabetes Mellitus
}

\author{
Authors \\ Dr Md Zamin Ahsan', Dr Taskeen Ahmad Reza', Dr Pramod Kumar Agrawal ${ }^{3}$, \\ Dr Rakesh Raushan ${ }^{4}$ \\ ${ }^{1}$ Junior Resident, Dept. of General Medicine, Katihar Medical College and Hospital \\ ${ }^{2}$ Professor, Dept. of General Medicine, Katihar Medical and Hospital \\ ${ }^{3}$ Professor and Head, Dept. of General Medicine, Katihar Medical College and Hospital \\ ${ }^{4}$ Senior Resident, Fortis Escort Heart Institute, Okhla Delhi
}

\section{Background}

In type 2 diabetes with secondary OHA failure, therapy with combination of multiple oral hypoglycaemic agents or combination of oral hypoglycaemic agent with insulin is known to improve glycemia in patients with type 2 diabetes mellitus, the best combination to achieve target fasting plasma glucose concentration of less than $130 \mathrm{mg} / \mathrm{dl}$ or glycosylated hemoglobin (HbA1C) below $7 \%$ is not very clear.

\section{Aims and Objectives}

1) To study the effect of combination oral hypoglycaemic agent with and without insulin on glycemic control, lipid profile and BMI.

2) To compare the beneficial effects in the above two study group

\section{Methods}

This present study was a cross sectional, hospital based, non-randomized, and comparative study conducted at the hospital attached to Katihar Medical College. A total of 100 Type 2 DM patients fulfilled the inclusion criteria, divided into two groups: those who received combination of oral hypoglycemic agent with the insulin (comb OHA+INS) and those who received combination oral hypoglycemic agent (comb OHA) alone. These groups were evaluated for baseline demographic, diabetic characteristics, glycemic control, lipid profile and BMI. These two groups were compared with respect to glycemic control, lipid profile and BMI.

\section{Results}

Both groups showed poor glycemic control. Proportion of patients with $\mathrm{HbA} 1 \mathrm{C}<7 \%$ is $9(18 \%)$ in comb OHA group and $13(26 \%)$ comb OHA+INS group $(\mathrm{P}>0.01)$. The proportion of patients with FBS <130mg/dl and PPBS <180 $\mathrm{mg} / \mathrm{dl}(\mathrm{p}<0.01)$ was significantly better in patients with comb OHA+INS group, shows better short term glycemic control. However, no significant difference in the lipid profile and BMI were found in either group. 


\section{Interpretation and Conclusion}

In type 2 diabetes with secondary OHA failure, therapy with either the combination of multiple OHA or combination of OHA with insulin, only smaller proportion of patients achieved the glycemic target $\left(\mathrm{HbA}_{1 \mathrm{C}}<7\right)$ while poor long term glycemic control $\left(\mathrm{HbA}_{1 \mathrm{C}}>7\right)$ was seen in majority of patients among both groups.

Mean $\mathrm{HbA}_{1 \mathrm{C}}$ is achieved well among patients on comb OHA+INS treatment group whose mean duration of diabetes was longer as compared to patients on comb OHA treatment group whose mean duration of diabetes was shorter.

I conclude that, early initiation of intensive insulin therapy may benefit all patients with diabetes irrespective of mean duration of diabetes

Keywords: Diabetes; $\mathrm{HbA}_{1 \mathrm{C}}$; Comb OHA; Comb OHA+INS.

\section{References}

1. Turner RC, Coll CA, Frighi V, Holman RR. For UK prospective diabetes Study group: Glycemic control with diet,s ulfonylurea, Metformin or Insulin in patient with type 2 Diabetes Mellitus; progressive requirement for multiple therapies (UKPDS 49) JAMA 1999;281: 2005-2012

2. Franz MJ, Warshan H, Daly AE. Evolution of diabetes. Medical nutrition Therapy. Postgrad Med J 2003;79:30-35.

3. Krall LP, Bradley RF. Secondary failure in the treatment of diabetes Mellitus with Tolbutamide and phenformin. Diabetes 1962;11:88-91

4. Delawtes DE, Moss SM.Tyroles's secondary failure of response to Tolbutamide treatment. 